\title{
"Pioneers"-The Druze Women School Principals as Role Models \& Generators of Social Change
}

\author{
Janan Faraj-Falah'1, Yossi Maman² \\ ${ }^{1}$ The Arab College for Education, Haifa, Israel \\ 2 The Western Galilei College, Akko, Israel \\ Email: jananf81@gmail.com,docmaman1@gmail.com
}

How to cite this paper: Faraj-Falah, J., \& Maman, Y. (2019). "Pioneers"-The Druze Women School Principals as Role Models \& Generators of Social Change. Creative Education, 10, 1573-1588. https://doi.org/10.4236/ce.2019.107114

Received: February 11, 2019

Accepted: July 21, 2019

Published: July 24, 2019

Copyright () 2019 by author(s) and Scientific Research Publishing Inc. This work is licensed under the Creative Commons Attribution International License (CC BY 4.0).

http://creativecommons.org/licenses/by/4.0/

\section{cc) (i) Open Access}

\begin{abstract}
The purpose of this preliminary study is to examine the attitudes of Druze women-school principals in relation to their role and its social significance. The research is qualitative, a "case study" of the phenomenon (Behrendt, 2017). Thus, in the "Holistic" research approach (Abuhav, 2013), the researcher is interested in revealing, learning and understanding the internal world of "subjects" from their point of By this approach, the origin of behavior is affected by definitions, beliefs, values and ideologies of the "subjects" (Pelto \& Pelto, 1978). The main field work is based on in-depth ethnographic structured interviews as a primary source for information, enabling the interviewee to tell her story freely and still being focused on the research questions. The interviews include 5 Druze women school principals to describe their own personal experiences (Spradley, 1979).
\end{abstract}

\section{Keywords}

Druze, Women Status, School Managers, Israel, Social Changes

\section{Introduction}

The inferior status of the Druze woman within their family, community and society, created great difficulties to leave home for acquiring higher education in the past, especially since some of the villages did not have high schools at all. However, three decades ago, Druze women began to study in Israeli universities, forced to face the traditional conservatism and closeness of the community. For example, the ban on leaving the village without a male escort or being in a mixed society or sleeping in remote cities outside the village. As a result, only few 
Druze families accepted and allowed their daughters to acquire higher education, yet, over the years, various Druze families begun also to send their daughters, breaking down the traditional and social barriers, and thus, today, many Druze women study at universities and colleges in Israel (Falah, 2000). Moreover, during their studies, the Druze women are exposed to Western democratic values, which fundamentally differ from the traditional authoritative approach they have grown up on (Al Haj, 1996). The turn to higher education has modified the Druze woman's inferior status, the well educated women became distinguished, greatly affect the Druze parents in general in favor of higher education. These women challenge the traditional norms, enabling other women to follow their path, and in fact, have created a social change in the social status of the Druze women. The acquisition of education enabled them to earn money outside the village while being exposed to knowledge, different manner of thinking, and to new innovative positions and attitudes, alongside with greater social involvement. This process created a "quiet revolution" that affected the social structure and status of the Druze woman and thus, the social structure of the Druze community. The educated women, who returned to their villages, have influenced the status of other women in general. Unlike other "Western feminist revolutions", which are aimed against the "male world", the unique quiet characteristic of the change draws its strength in its invisibility, thus, without a reason or desire to suppress. These women, who seek to change their status, challenge some traditional behaviors, and yet, maintain traditional norms, merely for breaking the veil of oppression and allow other women to join the process (Vinner-Levi, 2004). The purpose of this preliminary study is to examine the attitudes of Druze women-school principals in relation to their role and its social significance. The research is qualitative, a "case study" of the phenomenon (Behrendt, 2017). Thus, in the "Holistic" research approach (Abuhav, 2013), the researcher is interested in revealing, learning and understanding the internal world of "subjects" from their point of view (Denzin \& Lincoln, 2000; Toval-Masaiech, 2013). By this approach, the origin of behavior is affected by definitions, beliefs, values and ideologies of the "subjects" (Pelto \& Pelto, 1978). The main fieldwork is based on in-depth ethnographic structured interviews as a primary source for information, enabling the interviewee to tell her story freely and still being focused on the research questions (Kapl-Green \& Mirsky, 2013; Faraj-Falah, Maman, \& Amasha, 2017; Maman, Faraj-Falah, \& Napso, 2018; Fontana \& Frey, 2005). The interviews include 5 Druze women school principals to describe their own personal experiences (Spradley, 1979).

\section{Theoretical Background}

\subsection{The Druze in Israel}

According to the Central Bureau of Statistics, by the end of 2016, the Druze community in Israel was about 139,000 people, $1.6 \%$ of the general population of Israel. The Druze community is spread in 19 villages (17 villages in the Northern 
Province of Israel and two in Haifa District), with total fertility rate of (the average number of children a woman is having during a lifetime) of 2.2 children within 36,000 households, when the average age of the first marriage is 27.7 for men and 23.0 for women. It should be noted that according to the Central $\mathrm{Bu}$ reau of Statistics there is a great gap between the number of the working men (68.6\%) and the number of the working women (only 33.7\%).

The Druze, throughout history, has maintained good relations with the Jewish Nation, had supported the establishment of Israel and made a pact with the State. In 1957 the Druze had gained recognition by the Minister of Religious Affairs as an "independent religious community", and in October 1961, the Druze Religious Council (3 members) was recognized as the main spiritual authority. The process was completed on the 25th of December, 1962 with the approval of the Knesset of the Druze Religious Court to manage all Druze religious affairs. It is important to notice the religious distinction within the community, some Druze choose to be religious (the Ukal) with a clear definition of dressing code, customs and lifestyle, and some are secular (Johal), yet, the religious leaders also responsible beyond religious matters (Shtrukman, 2010). In addition, the Druze religion prohibits polygamy and women are equal to men, thus, women are entitled to perform any religious role, as well as to equal inheritance (Faraj-Falah, 2016a).

The Druze community conducts conservative traditional patriarchal lifestyle (Amarani, 2010; Halabi \& Shamai, 2016; Faraj-Falah, 2016b) with a constant concern to maintain the Druze core values and tradition such as Druze religion, tradition, independence and relation to land (Falah, 2000). The Druze family is characterized by a distinct hierarchy, which is emphasized by an absolute rule of the father on the extended family-his wife, sons, daughters, the sons' brides and offspring. They all required to abide by the family elders and to put the family goals in priority to personal ones (Dana, 2003). In this manner women's inferior status within the family is obvious, they are required to take care of the household and children, to dress modestly, to avoid contact with strangers and to obey their husbands. However, the status of women in the Druze society is not static and it constantly improves and empowered, as they grow older, mainly, as a result of their sons' marriage and the establishment of their own family units near their parents and to the increase of the extended family. The mothers' experience and involvement in their sons' marriage, the family affairs and the interaction with their brides, who are bide to obey the mother in law, only strengthen their status within the family (Vinner-Levi, 2005a; Vinner-Levi, 2005b).

Researchers (Faraj-Falah, 2005) indicate that since the 1990s it is clear that the Druze society is undergoing changes in all life aspects due to the following processes: 1) the young generation prefers living independently, thus, the extended family weakens. The focus is on the nuclear family of parents and children only. One element which accelerated this modification is the establishment of the new veterans' neighborhoods which totally differ from the traditional ones of the elder population. 2) The younger generation's independence, alongside 
with the increase of higher education, have undermined the authority of the religious much older traditional leadership. 3) $83 \%$ of the young Druze men, who take part in the compulsory army service, are exposed to different lifestyle, thus, the affinity to the clan (the extended family) weakens. 4) The progress in education has led to a change in the perception of the family role. 5) The frequent visits to the cities for the aims of working, entertainment or studying also have contributed to the exposure to the western culture. 6) Employment changes-the transition from a rural traditional source of income into other sources outside the Druze villages. 7) The change in the status of women by education and work. 8) The transition from the village to the city as part of the urbanism. 9) As opposed to the old, traditional, religious leadership, a new generation which has gained great power and senior governmental and security positions has risen. These changes have led to tension and division between the religious and secular parts within the community, to the point of declaring that-"the community members (the seculars) are becoming apart from their basic values, no values and no limits".

\subsection{Druze Women's Seeking for Work-Difficulties and Barriers}

Faraj-Falah (2016a) claims that the Druze woman always have worked beside her husband, she was responsible mainly for the farming and soil in the field and then was coming home to continue maintaining the household, from cleaning to cooking. Thus, the decrease in agriculture-the main source for bread, had damaged badly the Druze sector, and as a result, the Druze woman, who is subjected to residential radius restriction (Falah, 2000; Faraj-Falah, 2005; Faraj-Falah, 2018). Vinner-Levi (2004) claims that the Druze women in Israel suffer from twice over discrimination: one time is due to the fact that the community is a minority in a State which the employment opportunities for the Arab population in general and for women, in particular, are limited, and secondly, for being part of traditional and rigid society which restricts women from working outside their villages due to cultural-traditional reasons. The minority of Druze women who work is limited to specific professions and roles, in which, the salary is poor, such as community services, social services and industry-mainly in textile and food industries established by Jewish entrepreneurs within the Druze villages. Yashiv \& Cisar (2013) claim, on the other hand that, although the Druze woman's status is changing and there are more women that work in high-paying professions and senior positions, still, their integration in the Israeli labor market, in general, is poor, and they do not play a significant role in the Israeli economy in general or in their own family in particular, for the incentives to gain education and other social skills are minor. Fichtelberg (2004) argues that prejudice also makes integration in the Jewish labor market harder, due to traditional barrier of appearance, especially among religious women with religious-traditional clothing - as the head-cover for instance. The language-the non-native Hebrew, is also a barrier that prevents women from entering well-paid jobs and major professions, urging them to work in "small businesses" 
and in manufacturing, or at any service which does not require speaking the Hebrew language. Another barrier is the religious leaders of the community, who are against the work of women outside home and against academic studies, which sometimes compel women to sleep outside their homes and expose them to modern society (Faraj-Felah, 2005; Faraj-Falah, 2018).

\subsection{The Phase of Academic Studies}

The inferior status of the Druze women and their position on the margins of society and family hierarchy have made studying in higher education extremely difficult, especially the fact that some Druze villages lack of high schools in the past. Nevertheless, three decades ago, in the 1980s, Druze women in Israel began studying at universities, facing the traditional conservatism in the community, and the prohibition to leave the village without an escort of man or staying and sleeping in a mixed society or city for example. Therefore, very few families allowed their daughters to study, yet, over the years, Druze girls have joined the studying circle, breaking the social and traditional barriers. Hence, at present time, many Druze women enter universities and academic colleges (Falah, 2000). Furthermore, during their studies, Druze women are exposed to western, democratic values, which are fundamentally different from their traditional community (Al Haj, 1996). The decision to purchase higher education has modified their inferior, poor status. Thus, the distinguished status that these educated Druze women had acquired within the community, had led parents to send their daughters to study in the higher education system. These women challenge the old traditional norms and enable others to follow their path and to generate the social change for Druze women. Gaining of education enables working outside home and outside the close surroundings radius, and to be exposed to knowledge, a different way of thinking and other innovative perceptions, along with other social involvement. This process created "a quiet revolution" that affects the social structure and the status of the Druze woman in general. The unique nature of the change was the fact that it was not a "western feminist revolution" towards feminine world-unity, and not against the "masculine world" either, in fact, its main power was for being almost invisible, and thus, could not be immediately repressed. Those women, who seek to modify their status, on the one hand challenge traditional, and on the other hand, maintain the norms and tradition. Their main purpose is to break through the barriers of repression and to allow other women to be also part of the process (Vinner-Levi, 2004). However, for these traditional women, taking part in higher education is extremely empowering interculturally, for they become aware to the inequality and the gap between competence and traditional restrictions, which create constant difficulty in daily routine. Education has led women to gain knowledge and be open-minded, to work and earn money, yet, in many ways, education was not the liberating factor, merely an awareness-raising factor of equality, patriarchal domination and oppression, thus, along with feeling proud and successful, they also felt pain (Vinner-Levi, 2006). Today, the Druze perce- 
ive the "ideal woman" differently, if once a woman was judged by religious ruling and her personal status was based on Druze religion and traditions, today, her status is based on modern-cultural perceptions (Moadi, 1998). On the other hand, claims that the social structure of the Druze community is not homogenous, hence, processes of modernization do not enter equally to all Druze communities, therefore, some of the Druze communities are more conservative than others, that is to say, some Druze communities maintain the values and tradition more than others.

\subsection{Education in the Druze Sector}

Education in the Druze sector has undergone great changes over the years, in order to examine education in the Druze sector, two public committees have been established-the "Ben-Dor Committee", headed by Prof. from Haifa University, and "Shechterman Committee", headed by the Knesset member Shechterman, who was, at that time, the Head of the Knesset Education and Culture Committee (Falah, 2000; Falah-Faraj, 2005). The two committees recommended to exclude the sector from the Arab education system and to integrate the sector within the general one. Those recommendations were carried out, and the Druze education sector became independent in 1976. The educational system includes elementary and higher education. Falah-Faraj (2005) indicates that in the past, until the third or fourth grades, boys and girls had learned together and were separated afterwards. In the village of Majar, for example, boys and girls had separate schools. According to the researcher, this separation of genders indicates conservative perception and restrictions of women, which had prevented from them (the women) to break through the suffocating barriers and restrains until this day.

\subsection{Women Principals}

In the modern, constantly developing era of today, it is evident that women have managed to break through the barriers and to serve in various positions that once were defined as appropriate for men only, especially in the field of education. Thus, Druze women find themselves managing schools, yet, the nature of their successful management is relatively limited. Naturally, the subject has been examined, some believe that since the principals operate in an environment characterized by male hegemony, in view of differences in the process of socialization and life experience, significant differences in gender management can be discerned managing bin masculine environment, and in the light of differences in socialization process and life-experience, there must be significant differences in management style. Moreover, the gender differences indicate of distinction between the way women did to acquire their status, and they also indicate the differences in the way women experience the process. Others argue that gender identity is formed and developed by the role and position in accordance with the context of activity. Some researchers believe that there are no substantial gender differences in managing style. Female school principals in the Druze sector are 
women with higher-academic education, who have invested great time and efforts as teachers and were promoted to executive position, and in this manner, acquired their respect and status, becoming a role model for other women, facing the conservatives sheikhs who constitute the main barrier for many young Druze. It should be noted that the first female school manager in the Druze community was Mrs. Salma Kasem Falah, who was appointed to the post in 1960 (only after 25 years additional women were appointed too). At present, there are several Druze women who run elementary and high schools. In addition, there are many women who succeeded in other fields and senior positions such as Mrs. Huria Shami Birani from Daliat El-Carmel, who was the first Na'amat Coordinator in the early 1960s. The first Druze woman who got an academic degree is Mrs. Samira Abu Rokken from Ausafiain the early 1970s (Falah-Faraj, 2005).

\section{Research Methodology}

This study is a qualitative research, a "case study" of the phenomenon (Behrendt, 2017). Thus, in the "holistic" research approach (Abuhav, 2013), the researcher's aim is to reveal, to learn and to understand the inner world of the "subject" from one's point of view (Denzin \& Lincoln, 2000). According to this approach, behavior is rooted in the environment, beliefs, values and ideologies of the "subject" (Pelto \& Pelto, 1978). Most of the field-work was based on in-depth ethnographic interviews as the prime source for information, allowing the applicant to tell her story freely, and at the same time, to remain focused on the research questions (Kapel-Green \& Mirsky, 2013; Shkedi, 2011; Faraj-Falah, Maman, \& Amasha, 2017; Maman, Faraj-Falah, \& Napso, 2018). The interviews were conducted with 5 Druze school principals, in an attempt to share their own personal experience (Spradley, 1979). The date for the interview was coordinated by phone, and the interview itself was carried out in their home and lasted about 50 minutes (for each interview), their words were documented in writing (Table $1)$.

As mentioned above, the interview was "structured", on the basis of pre-made questions (Wilson \& Onwuegbuzie, 2016; Hugh-Jones, 2010; Faraj-Falah, Maman, \& Amasha, 2017; Maman, Faraj-Falah, \& Napso, 2018) by the following order.

Table 1. The interviewees.

\begin{tabular}{ccccccc}
\hline No. & Name & Age & Marital Status & Residence & Academic Degree & Managing Experience \\
\hline $\mathbf{1}$ & Nuha & 57 & Married & Kisra & M.A. & 10 \\
$\mathbf{2}$ & Salma & 80 & Married & Acre & Senior teacher & 3 \\
$\mathbf{3}$ & Shadia & 30 & Married & Yarka & M.A. & 7 \\
$\mathbf{4}$ & Shirin & 36 & Married & Yarka & M.A. & 3 \\
$\mathbf{5}$ & Janan & 38 & Widow & Smi'a & M.A. & 4 \\
\hline
\end{tabular}


1) What roles have you had?

2) Why did you apply for the position of management?

3) Tell me who applied to the position and why do you think you have won?

4) Who supported/did not support your decision to apply for the position?

5) What is the qualification you have gained in management over the years?

6) Does a female manager have an advantage over the male one, why?

7) What is your personal vision as a school principal? Specify

8) Do you think your winning of the position is significant for the Druze woman?

9) What do you-a Druze woman manager represents for women in the Druze society?

10) Do you expect a change in Druze women's status?

After collecting the data, by the use of built-in interview, a careful reading and analysis were done, in accordance with the categories of each question alone. This process reflects the Etic approach (Givaton, 2001; Miles \& Hubermaan, 1994). The analysis of the content of each question was done by the Emic approach, namely, to construct the context topics and sub-topics out of the answers (Miles \& Hubermaan, 1994; Bawa, 2017). Tsabar (1995) argues that there are no shortcuts in this process, the researcher is required to look for the obvious (visible), prominent, important and repeated components, to rephrase the classified categories, select and choose the units for analysis, and placing the sections (Shkedi, 2010; Charmas, 2005; Perakyla, 2005; Shanthi, 2017). Shkedi (2003) adds that in the course of reading of the data, we think how to associate the words and phrases into categories which become meaningful only in relation to other categories.

\subsection{The Way to the Job}

\section{1) Former positions}

All interviewees were teachers, except for Shadia, who was a counselor and social worker. Selma, the first Druze school-principal in Israel, notes with pride, "I have been a teacher for more than 30 years. Janan was a special education teacher and coordinator, while Shirin was a Hebrew teacher, social coordinator, a deputy head of school and educational consultant". Nuha states, "I filled a variety of roles: I was a science teacher and tutor, and led to changes in methods of teaching and evaluation in the Druze and Jewish schools in the course of instructing the project of PISGA". As a pedagogical coordinator, I have led to a change and improvement of core subjects. I also was part of school management team and the decision-makers; I was a tutor in the "Executive Program" after I was appointed to be a junior high school principal.

\section{2) Winning the position}

Janan and Nuha attained the position at school after the position was vacated. Janan got the job due to difficult circumstances of the death of the late school principal, as she describes "The loss of my Principal". The other three principals were part of school team, getting the position on the basis of their professional 
skills, as Salma indicates "I was a hardworking teacher, therefore I was offered the position at school". Shirin adds, "I had made many trainings and roles. I worked systemically within the system and also was the coordinator of 'Perach Project' in some villages".

\section{3) The tender and winning of the position}

As stated, the selection for school management is done via tender. Salma describes, "I don't recall if there was a tender at that time, for it was much different from today. I accepted the position out of honor and appreciation, there is no doubt that the role is difficult and requires great responsibility". Nuha remembers that she was the sole nominated to the position, while Shadia emphasizes that, "Only one additional woman competed in the tender". In contrast, Janan and Shirin reported that in their tinder, men also applied, in the case of Shirin, "there were 2 women and 8 men". The women-principals also refer to their selection of the position, stating their personal skills and abilities, which were already emphasized in former positions, as Salma explains "My superiors knew that I am fit to the position and would manage to handle the role and tasks. They believed in me, in my skills and features, knowing that I am a strong, hard-working employee who can succeed in the position, my work did not interfere my domestic duties at home, I have always managed to complete all tasks. It is not easy and requires great efforts and will, yet, it is achievable. It is all about positive thinking". Shirin adds, "It is my personal qualities-the belief n myself and in people and in the notion of change, this my vision throughout the roles and positions I have filled. The rest of the school-principals (Shadia, Nuha and Janan) attributed to their professional training in winning the position.

4) Support and lack of support during the tender and afterwards (attaining the tender and winning it)

The women emphasize both the support they had in attaining the tender and after winning it. Janan, Shadia and Shirin indicate the emotional support hey have gained from their spouses "He encouraged me to attain the tender, it's mainly an endless, emotional support.", whereas in the case of Salma, her family had supported her "During winning the position I was still single. I was supported by my parents, as usual". Apparently, her husband had a significant role later on "After I got married, I got the support from my husband, who always stood by me. He supported me from the beginning, encouraged me and stood by me all along". Nuha specifies the unique contribution of her husband to her success. "My husband is a doctor. He runs a Clinique and has a senior managerial role HMO. We constantly consult and share our professional challenges, in an effort of finding solutions to our problems at work, both in education and medicine. His understanding and willingness to assist me in any situation are a cornerstone of my success as the head of school, without the help and support of my family it would be difficult to engage full-time at school, home and family has a great part in providing the strength to cope with the challenges. My husband supports and assists, and therefore, the dynamic at home is always calm and understanding and it tremendously affecting my success". Shirin and Nuha 
add that they have a support also from their wider circle of people "key role members in the municipality, as well as from religious figures, the teachers, the school staff and parents. They were all supportive".

Apparently, after winning the tender, the school staff had a major role in the process of adjustment to the administrative role. Thus, Nuha explains "In general, every change is accompanied by opposition, especially in the educational system, yet, I never encountered problems, the fact that I was once part of the teaching staff and grew out of school was and still very helping, for I already knew my staff and school, thus, I could overcome the difficulties and find solutions with the aid and collaboration of my teamwork. Thus, legitimate claims and concerns of parents were also handled calmly and with full understanding and willingness by me and by my staff, in an attempt to find the best solution for all sides". Salma adds in relation to the staff that: "The school's surrounding and staff appreciate my skills and abilities and supported me to the job, as for the support outside school, I had not had to face problems, some of my relatives are also teachers and they helped me". At the same time, the principals (Salma, Janan, Shirin and Sadia) also stated the lack of support during the tender, "There were some negative reactions, mainly from parents and people from the village out of fear, for our society is conservative."

\subsection{The School Principal as a Woman of Vision}

1) The management training

All principals, except for Salma, have gained in the curse of working management training. Salma claims that "I teach since the 1960s; I was a very hard-working manager. At that time, the teachers and the management were also assisting cleaning the classrooms, yet, I also had some educational trainings". Janan, Shirin and Shadia emphasize their management training coarse, yet, only Nuha choose to specify in detail the nature of her administrative training I had participated in "Educational Coordinators Course" for two years, in addition, I had a course of "Leadership towards Improvement" for two years, then, for a year, I took the course of "Developing of School Management Team" and in 2011-2012 a "management training course, and two years later, an Educational Initiative Course".

\section{2) The advantage in woman's management}

Out of the five women-principals, four women believe that female style of management is better than that of male, they refer it to motherhood. Nuha emphasizes patience as a trait mainly of mothers "I believe that a woman who is also a mother is by nature more tolerant and attentive, and therefore more consistent. Woman, in general, is able to manage better than man complicated situations with much more patience. There is no situation more complex than managing school". Salma, on the other hand, emphasizes the assertive side of motherhood, "Mothers have strong character, they are assertive, caring and responsible, good educators of their children, therefore they are able to run school successively". Shirin believes that "Mothers have a much better ability to maneuve- 
rinter personal communication, a trait which enables to run a school". Janan and Shaida, on the other hand, believe that the skills which contribute to their success are irrelevant to the fact of being women, "A principal, whether it is a woman or man, depends on the following features of leadership: responsibility, motivation as well as of the ability to change and being changed".

3) The personal vision of the principal

Each principal has deployed us her special, personal vision. Shirin attaches importance to all aspects of education as the basis for growth and development, "I aspire to create major changes in the organization, that is to say, a significant improvement of educational milestones such as-listening and empathy and at the same time to become a role model with a strong inner voice, to succeed in finding the positive aspects in each person, whether it is a pupil, teacher or parents". Salma and Janan extend and emphasize the importance of interaction between the school-principal and the people around, "The vision is first of all to be able to maintain good relations with everybody, especially with the teachers. I keep in touch with the teachers and students who respect me for my efforts and work. I have made an annual plan of school activities for the teachers, and thus, won the respect and praise of my supervisors in the Ministry of Education, as a result, the teachers were also appreciated and did not get fired even in cases of criticism. Shadia presents a different vision she has strived to achieve, in which, school would follow multicultural principles," School should be home for all student, regardless of their origin or surrounding, to serve them professionally, to educate and be culturally supportive and based on multiculturalism, acceptance of the other and respect, to aspire to lead the students to utilize their ability to the best, to empower and to develop life skills and self-esteem in order they would become better citizens. Nuha was careful to describe her credo, "I believe that education is the way to improve the status of the individual and to create involvement in all life aspects. I believe in the right of every individual to live in peace and be secured, therefore, it is important to create an educational climate that protects and condemn any kind of violence. I believe in educating towards values and mutual respect, to determine social norms that would protect the student and would enable one to learn. I believe in training the new generation to face the constant development of science and technology of modern society. I believe in a person's natural creativity, the use of this talent will turn a student into a better person, to become thoughtful and respecting and more involved and tentative to society."

\subsection{The Female Druze Principal as a Generator of Social Modification}

\section{1) The managerial role as a turning point for the Druze women}

All the interviewees said that winning the position and becoming a principal are substantial to the Druze woman's status. Only Nuha and Salma referred to the extent of the change, according to Nuha, "This is a change in the status of women, it follows other important modification in positions in medicine, engi- 
neering and economics." Salma was the only woman that specified the change in detail: "It certainly indicates a change in the status of the Druze woman. Managing demand higher education, experience, managerial qualities as responsibility, long-term vision, caring and great investment of time beyond the work hours, an element which might be a barrier to some Druze women, for it requires investment of time in training and seminars on the expense of the family, an element which was not common in the past. It is definitely a turning point in the Druze woman's status, which undergoes a significant change in all life aspects due to her exposure to modern innovations and to the Israeli society."

2) The female school principal as a role model for women in the conservative Druze society

All principals-interviewees believe that they are a positive role model for women in the Druze society. Shirin shares with us a personal interaction with a girl from her village, "One of the village girls came to me and asked me-how I manage, as a Druze woman, to hold to my position? And I applied that, if you put your mind to it you can accomplish anything, she said in return that I am a role model for her. I was pleased. In fact, I always encourage women to follow their dreams". Nuha referred to the good treatment that the Druze woman receives in general, "Druze woman does not suffer religious coercion, she can be either secular or religious, yet, she is committed to preserving the Druze customs such as family honor, self-respect, and to protect the homeland. I think that a female-principal is a symbol of honor in our society, for it educates students towards a development of national and religious identity, an example of coping and maintaining of the rights to live honorably within the Israeli society, uttering the women's efforts to obtain equality of rights and opportunity as men, it is a fact that we manage to fit in almost all aspects". Salma refers to a "golden mean"- the merging between traditional values and being a unique role model to society "I always kept a modest dress code and the religious values, despite living in the city, after my retirement I became even more religion. I began reading religious stories and become an expert in Druze religious matters. Furthermore, I wrote three religious books and gave them for free, for I believe it is extremely important to maintain our values and tradition and not crossing this line. As a school manager, I encouraged many students who dropped out to go back to school. I love to help and contribute to society, I volunteer in hospital with senior citizens and with students-to get them a scholarship. At school, I invested great time in developing sewing classes, painting and reading. I know that Gordon College had dedicated a space to present my work, as a symbol of a woman breaking barriers, who had managed to get out of the suffocating conservative bubble".

3) The change in the Druze woman's status in the future

All subjects (principals) believe that the future holds a significant change in the status of Druze women. Thus, Shirin states, "The change is already here, the Druze woman is not limited in many aspects, and I expect more improvements in the future", while Salma claims that the change is due to higher education, 
"Today, most of the Druze women are well educated and hold academic degrees. Those women strive to succeed, to aid and support their family, and at the same time, to advance and improve their own status among the Druze community in particular, and in the Israeli society in general. Hence, there are Druze women in managerial positions, who leave their village to work in the city, an element which indicates of the modification of perception and the development in the Druze woman's status". Nuha, as well, believes that the key to the change in status is related to educational attainment and adds the following statement: "We experience great changes, Druze woman's promotion is associated with education, knowledge provides tools and enables coping with the enormous changes in modern society. I have no doubt that the Druze woman will succeed in the era of technology and science, to enter to higher positions in the hi-tech industry, and as a result, to take over the Druze leadership and be part of the decision-making processes within the congregation, to become a representative in the Druze Religious Council and Court, and to keep striving for her rights and gender equality."

\section{Summary}

The aim of the current article is to comprehend the different perceptions of the Druze (women) school principals in relation to their position and status in the Druze community.

The interviewees support the researchers' hypothesis-Falah-Faraj (2005) and Shtrukman (2010), who assume that the improvement in the level of education has led to a change in status of the Druze women, especially in relation to position at work. It should be noted that all the findings support Vinner-Levi's (2004) hypothesis, assuming that women academization have made these women to be "groundbreaking" in the Druze society, forcing the parents to send their daughters to college, and in this manner, to be exposed to different opinions and to more innovative manner of thinking. The researcher names the process "the quiet revolution".

In light of the research findings, we support this hypothesis and try to validate it by the following expressions, one by one:

1) We are aware of the modification in attitude within the "family unit" - If in the past the sole role of Druze woman was to raise her children, housekeeping, within the village, now the role is changed, particularly in relation to her family and spouse-her husband supports her in her decisions, that is to say, before attending the Tender and afterwards. The support is moral and mental, emphasized by advising her in relation to the managerial position.

2) Becoming a school manager is done by the method of "grown manager"-a teacher who fulfills successfully varied roles inside and outside school towards modification, she is developing gradually, from being part of the school's staff to management, gains her strength as a result of being once part of the staff, as in contrast to a school manager who is appointed externally, an outsider. 
3) The Druze women managers relate advantages to their gender, for they attain the position well prepared due of being mothers(with patience, attentiveness, consistency, assertiveness, coping with complicated situations, maneuvering skills, personal communication), thus, they are well "aware" and wisely using those qualities in their daily work.

4) Although the personal vision of each school manager differ, nevertheless, they all attribute great importance to the promotion of the individual- "finding the light in every person" (Shirin), "having a good interaction with everyone" (Salma and Janan), "to use wisely a person's natural gift" (Nuha). The vision of each one of them is realistic.

5) It should be emphasized that the female managers believe they are a "role model" for the Druze women and their community.

\section{Conflicts of Interest}

The authors declare no conflicts of interest regarding the publication of this paper.

\section{References}

Abuhav, L. (2013). Teaching Qualitative Research Methods: Going Out into the World and Inner to Myself. In O. Chazan, \& L. Netov (Eds.), Qualitative Research Teaching: Challenges, Principles, Implementation (pp. 53-77). Tel Aviv: The Mofet Institute.

Al Haj, M. (1996). Education among Arabs in Israel. Jerusalem: Magnes, Floressheimer Institute, The Hebrew University of Jerusalem.

Amarani, S. (2010). The Druze between Community, Nation and State, Chaicin Cathedra of Geostrategic, the University of Haifa.

Bawa, P. (2017). Making Sense of Making Meaning, the Semiotic Way: Emotional Journey of a Novice Learner. The Qualitative Report, 22, 73-104.

Behrendt, M. (2017). Examination of a Successful and Active Science Club: A Case Study. Science Educator, 25, 82-87.

Charmaz, K. (2005). Grounded Theory in the 21st Century: Application for Advancing Social Justice Studies. In N. K. Denzin, \& Y. S. Lincoln (Eds.), The Sage Handbook of Qualitative Research (3rd ed., pp. 507-535). London: Sage Publications.

Dana, N. (2003). The Druze in the Middle East: Their Faith, Leadership, Identity and Status. Brighton: Sussex Academic Press.

Denzin, N. K., \& Lincoln, Y. S. (2000). Introduction: The Discipline and Practice of Qualitative Research In N. K. Denzin, \& Y. S. Lincoln (Eds.), Handbook of Qualitative Research (2nd ed., pp. 1-28). London: Sage Publication.

Falah, S. (2000). The Druze in the Middle East. Jerusalem: The Defense Ministry Publishing.

Faraj-Falah, J. (2005). The Druze Woman. Rishon Lezion: Barkai Publications.

Faraj-Falah, J. (2016a). The Status of Druze Women in the Druze Religious Law in Comparison to Druze Women's Status. International Journal of Multidisciplinary Research and Development, 3, 203-206.

Faraj-Falah, J. (2016b). She Is a Widow: The Story of Six Druze Widows in Israel. Open Journal of Social Sciences, 4, 210-226. http://www.scirp.org/journal/jss https://doi.org/10.4236/jss.2016.49018 
Faraj-Falah, J. (2018). "HeIs Alienated”: Intermarriage among Druze Men in Israel. Sociology Mind, 8, 70-82. https://doi.org/10.4236/sm.2018.81005

Faraj-Falah, J., Maman, Y., \& Amasha, W. (2017). Brides across the Border (Syrian Druze Bribes Who Have Married Israeli Druze Men of the Golan Heights after the Israeli Occupation in 1967). Open Journal of Social Sciences, 5, 289-303. https://doi.org/10.4236/jss.2017.55021

Fichtelberg (2004). The Participation of Palestinian Woman in the Labor Force in the Past Decade. Qeriat Ben Gorion: The Ministry of Labor and Social Affairs of the Authority of Personnel Planning.

Fontana, A., \& Frey, J. H. (2005). The Interview: From Neutral Stance to Political Involvement. In N. K. Denzin \& Y. S. Lincoln (Eds.), The Sage handbook of qualitative Research (3rd ed., pp. 695-727). London: Sage Publication.

Givaton, D. (2001). A Theory Supported in the Field: The Meaning of the Data Analysis Process and the Construction of Theory in Qualitative Research. In N. Tza-bar (Ed.), Traditions \& Trends in Qualitative Research (pp. 195-228). Tel Aviv: Dvir.

Goldblatt, H., \& Bend, T. (2013). Between Understanding \& Insights: Reflective Teaching in Qualitative Research. In A. Hazan, \& L. Notov (Eds.), Teaching Qualitative Research Challenges \& Principals for Implementation (pp. 209-241). Tel Aviv: The Mofet Institute.

Halabi, J., \& Shammai, M. (2016). The Israeli-Civil Identity among the Druze Adolescents in Israel, and the Implications of the Violation of Civil Rights of the Arab Minority on This Identity. In L. J. Jabarin (Ed.), The Photo: Sara Ozacki, Conditional Citizenship-About Citizenship Equality and Harmful Legislation (pp. 297-326). Haifa: Pardes Publishing House.

Hugh-Jones, S. (2010). The Interview in Qualitative Research. In M. A. Forrester (Ed.), Doing Qualitative Research in Psychology (pp. 77-97). London: Sage Publications.

Kapel-Green, A., \& Mirsky, Y. (2013). “This Place Is to Me a Nature Reserve That Really Needs to Be Preserved": A Portrait of a Turning School in the Eyes of His Team Members. In B. Alpert, \& S. Shalsky (Eds.), The School and the School at a Closer Look-Ethnographic Studies on Education (pp. 108-140). Tel Aviv: The Mofet Institute (In Hebrew).

Kopel-Green, A., \& Mirsky, Y. (2013). This Place Is in My Nature Reserve Portrait of Mifneh School in the Eyes of His Staff. In B. Alpert, \& S. Shlasky (Eds.), The Class \& School on Closer Inspection-Ethnographic Studies (pp. 108-140). Tel Aviv: The Mofet Institute.

Maman, Y., Faraj-Falah, J., \& Napso, E. (2018). The Social Adjustment of Girls Circassian Students in State Elementary Schools. Open Journal of Social Sciences, 6, 230-245. https://doi.org/10.4236/jss.2018.61017

Miles, B., \& Hubermaan, M. (1994). Qualitative Data Analysis: An Expanded Sourcebook. Thousand Oaks: Sage Publication.

Moadi, C. (1998). The Druze Woman. In D. Nissim (Ed.), The Druze (pp. 111-119). Ramat Gan: Bar-Ilan University.

Pelto, P., \& Pelto, G. (1978). Anthropological Research: The Structure of Inquiry. Cambridge: Cambridge University Press. https://doi.org/10.1017/CBO9780511607776

Perakyla, A. (2005). Analyzing Talk and Test. In N. K. Denzin, \& Y. S. Lincoln (Eds.), The Sage Handbook of Qualitative Research (3rd ed., pp. 869-886). London: Sage Publications.

Shanthi, T. (2017). Teacher Empowerment: A Focused Ethnographic Study in Brunei Darussalam. The Qualitative Report, 22, 47-72.

Shkedi, A. (2003) Touching Words-Qualitative Research: Theories \& Implementation. Tel 
Aviv: Tel Aviv University.

Shkedi, A. (2010). A Theory Supported by Narratives: Constructing of a Theory in Qualitative Research. In L. Kassan, \& N. Cromer (Eds.), Qualitative Data Analysis (pp. 436-446). Be'er Sheva: Ben-Gurion University of the Negev.

Shkedi, A. (2011). Meaning behind Words: Methodologies in Qualitative Research in Practice. Tel Aviv: Tel Aviv University.

Shtrukman, M. (2010). The Principle of Pluralism and Its Realization in the State of Israel. Tel Aviv: MATAH.

Spradley, J. (1979). The Ethnographic Interview. New York: Rinehart.

Toval-Mashiach, R. (2013) Challenges and Tensions in Qualitative Research in the Social Sciences. In A. Hazan, \& L. Netov (Eds.), Qualitative Research Teaching: Challenges and Principles of Implementation (pp. 23-51). Tel Aviv: The Mofet Institute. (In Hebrew)

Tsabar, N. (1995). The Qualitative Research in Teaching. Darya Ganj: Modan Publications.

Vinner-Levi, N. (2004). "I Am a Bird, Yet Not Flying" The Identity of the First Druze Women Who Applied for Higher Education. Doctoral Thesis, Jerusalem: The Hebrew University of Jerusalem.

Vinner-Levi, N. (2005a). "I Was Called Umm al-Futa": Higher Education as an Intercultural Encounter.

Vinner-Levi, N. (2005b). Higher Education as an Encounter of Opinion, Society and Culture. Changes in the Identity of Pioneer Druze Women in Acquiring Higher Education. Social Issues in Israel-Social Journal, No. 1, 5-30.

Vinner-Levi, N. (2006). The Work of the First Female Druze Teachers-Towards the Promotion of Education and to the Change of Gender Roles among Their Students. A Research Report Submitted to the Mofet Institute.

Wilson, A., \& Onwuegbuzie, A. (2016). Using Paired Depth Interviews to Collect Qualitative Data. The Qualitative Report, 21, 1549-1573.

Yashiv, E., \& Cisar, N. (2013). The Labor Market of Israeli Arabs. TTel Aviv: Tel Aviv University. 